\title{
FACTORS INFLUENCING ELECTRONIC COMMERCE IMPLEMENTATION IN DEVELOPING COUNTRIES: EVIDENCE FROM NIGERIAN BANKING SECTOR
}

\author{
${ }^{1}$ OLAJIRE, S. O., ${ }^{2}$ AGBOOLA, O. S. \& ${ }^{3}$ ADEOYE, M. A. \\ ${ }^{1,2,3}$ Department of Management and Accounting, \\ Ladoke Akintola University of Technology, Oyo State, Nigeria. \\ E-mail: ${ }^{1}$ olajire56@gmail.com, ${ }^{2}$ fodio123@gmail.com, ${ }^{3}$ mabowale@gmail.com
}

\begin{abstract}
The advent of internet coupled with advances in information, communication and technology has revolutionized ways of doing business leading to conducting business through electronic commerce. This paper examined the factors influencing electronic commerce implementation in the Nigerian banking sector. Primary data were sourced through the administration of questionnaires. A total of nine banks were randomly selected for this research comprising of Access Bank, GT Bank, (with international authorization); Ecobank, Polaris Bank, (with national authorization); Sunrise Bank, Providus Bank (with regional authorization); Rand Merchant Bank, Nova Merchant Bank (merchant bank); and Jaiz Bank (non-interest bank). Discriminant analysis was adopted to analyze the study hypotheses. Discrimination is achieved by setting the variate's weight for each variable to maximize the between-group variance relative to the within group variance. Findings revealed that Top Management Support, IT Capability, and Perceived Benefit have positive impact on e-commerce implementation. It is therefore, recommended that the banking sector should improve on the adoption and implementation of e-commerce in Nigeria.
\end{abstract}

Keywords: e-Commerce, banking sector, discriminant analysis. 


\section{INTRODUCTION}

Advances in information and communication technologies and the emergence of the internet have revolutionized business activities enabling new ways of conducting business referred to as electronic commerce (Zwass 2013; Turban, King, Lee, \& Viehland, 2014). Electronic commerce (e-commerce) describes the process of buying, selling, transferring, or exchanging products, services, and/or information through computer networks, principally the internet (Turban et al., 2014). Zwass (2013) further held that Electronic commerce is the sharing of business information, maintaining of business relationships, and conducting of business transactions by means of telecommunications networks.

Electronic commerce activities include the inter-organizational processes of market-based sellbuy relationships and collaboration (Business-to-Business or B2B) and consumer-oriented activities (Business-to-Consumer, i.e., B2C, and consumer-to-consumer, or $\mathrm{C} 2 \mathrm{C}$ ), as well as the intra-organizational processes that support them (Zwass, 2013). Electronic commerce as a way of doing business has significant advantages; organizations are embracing e-commerce as a means of expanding markets, improving customer service, reducing costs, and enhancing productivity (Wenninger, 2009). The Internet allows for unconstrained awareness, visibility and opportunity for an organization to promote its products and services (Senn, 2010).

Despite the global reach of e-commerce, not all countries have taken advantage of or benefited from e-commerce. There is a big gap in internet and e-commerce adoption between the developed and developing countries (Licker \& Motts, 2010); thus creating a digital divide.

Mbarika, Okoli, Byrd and Datta (2015) stated that much of the discussion on digital divide has focused on that which occurs among different social groups; they note the existence of international digital divide between countries. According to them this digital divide is abundantly clear when comparing Sub-Saharan Africa with developed countries. The main obstacles that prevent developing countries from leveraging the internet are lack of adequate communication infrastructure, technical know-how, and information processing about the economy and environment. The lack of adequate banking infrastructure is also considered as one of the problems faced by developing countries in building e-commerce solutions (Khalfan \& Akbar, 2016). Nigeria with a population of approximately 180 million is a potentially lucrative market for e-commerce services.

The main objectives of this paper is to examine the e-commerce implementation level of banks and the factors that inhibit the wide implementation and use of electronic commerce in the Nigerian Banking Industry, and to rank the importance of such factors on the decision to implement and use ecommerce applications in Nigerian banks. 
Journal DOI: 10.46654/ij.24889849

Article DOI: 10.46654/ij.24889849.s65029

\section{LITERATURE REVIEW}

\section{E-commerce Implementation}

The dependent variable is implementation of e-commerce. In this study, implementation of ecommerce is defined as the use of computer networks, principally the internet, for sharing of business information; maintaining of business relationships; and conducting of business transactions (Turban et al., 2014; Zwass, 2013). The likelihood of e-commerce implementation was operationalized as a dichotomy: whether the business has or has not implemented ecommerce.

A business is defined as having implemented e-commerce if it achieved interactive e-commerce status. Molla and Licker (2015) identified a six-phase e-commerce status indicator, relevant to ecommerce in developing countries; they are: no e-commerce, connected e-commerce, static ecommerce, interactive e-commerce, transactive e-commerce, and integrated e-commerce.

Although research studies on e-commerce in developing countries have become popular, most of the research in Africa tends to be concentrated on South Africa (Barnard \& Wesson, 2013; Molla \& Licker, 2015; Moodley, 2013; Pather, Erwin \& Remenyi, 2013). However, the number of recent studies on e-commerce adoption in other parts of Africa has been growing (Nasri and Charfeddine, 2012; Asare, Gopolang and Mogotlhwane, 2012; Mashanda, Cloete \& Tanner, 2012; Taylor, Dorothy \& Owusu, 2012).

\section{E-commerce in Nigeria}

Internet usage in Nigeria is relatively low compared to developed countries while e-commerce is still in an infantry stage. Notwithstanding this, there is a growing awareness on the benefits and opportunities offered by e-commerce amongst Nigerians (Chung, and Payter, 2012). Ecommerce activity in Nigeria is steadily growing as a result of vast improvement in telecommunication services. The telecommunications Industry has experienced exponential growth with over 20 million telephone lines connected to date (Chwelos, Banbasat, and Dexter, A.S. 2011). Alongside this growth, there has been an increase in the number of private telephone operators offering fixed wireless service with data transfer capabilities leading to an increasing number of people with internet access at home in the major cities and in some rural areas. The recent advances in the telecommunications market, and the explosion in the number of subscribers, demonstrate the potential market for information, communication and technology services generally in Nigeria (Ndukwe, 2016).

Internet banking is slowly and steadily gaining grounds as banks have set up websites which publish corporate information and allow customers to carry out some form of transaction, 
however limited in most cases. Despite the growing focus on internet banking, not all banks are moving at the same pace, as some still have only informational websites. The initial advances that have been made in electronic banking is a step in the right direction and could be a motivator in the adoption of e-commerce services in Nigeria (EIU, 2016).

\section{Hypotheses Development}

Based on the extensive literature review described above, the following hypotheses were developed and stated in the alternate form.

\section{Top Management Support}

According to Tolbert and Zukar (2003), innovation of Information Technology would be more likely if the political environment within an organization has norms favouring the change. Thus, the implementation of e-commerce will depend on whether support from top management is available or not. Top management support has been identified as crucial in the acquisition and diffusion of innovation (Orlikowski, 2013).

E-commerce can potentially influence the organization's competitive position as well as its business relationships, therefore it is important that top management need to get involved in order to gain a good understanding of the issues surrounding e-commerce and mobilize organizational stakeholders (Epstein, 2014). Thus, we propose that $\left(\mathrm{H}_{1}\right.$ indicates hypothesis number 1):

$H_{1:}$ Top management's support and commitment will be positively related to e-commerce adoption.

\section{Information Technology (IT) Capability}

IT capability refers to the level of IT resources and personnel knowledge of an organization (Akbulut, 2012). Access to adequate equipment in the organization is a major determinant of the implementation of new technologies (Beatty, Shim, and Jones, 2001).

Cohen \& Levinthal (2010) stated that an organization's ability to appreciate an innovation, to assimilate it, and apply it to new ways is largely a result of the firms pre-existing knowledge in areas relating to the intended innovation. Implementation of e-commerce requires organizations to possess a set of IT-related skills and knowledge (Turban et al., 2014) such as telecommunication knowledge, IT security knowledge, and Internet application environment. Thus, we propose that:

$\mathrm{H}_{2}$ : A high level of IT resources can positively impact ecommerce adoption 


\section{Perceived Benefits}

Perceived benefits refer to the extent of managements recognition of the relative advantage of adopting e-commerce to the organization. Perceived benefits are an important factor in adoption of new innovations (Lacovou et al., 2015). Rogers (1983) defined relative advantage as the extent to which an innovation is perceived as better than the idea it supersedes or its nearest alternative. Relative advantage can be measured in financial terms; however, social status, comfort, and satisfaction are important factors as well. The greater the perceived relative advantage of an innovation, the more rapid its rate of adoption will be (Rogers, 1983). This view is supported by Lacovou et al. (2015); they found that perceived benefits have a positive effect on the likelihood of e-commerce adoption. The higher the appreciation of the benefits of ecommerce by management the more likely they are to set aside organizational resources necessary to adopt and implement ecommerce. Thus, we propose that:

\section{$H_{3}$ : A high level of perceived benefits will positively impact adoption of e-commerce.}

\section{METHODOLOGY}

The licensed banks in Nigeria which is made up of three categories, comprising of; commercial banks, non interest banks and merchant banks are the population of this research. There are a total of twenty-seven banks licensed to operate in Nigeria. The list comprises of nine commercial banks with international authorization, ten commercial banks with national spread, two commercial banks operating at regional level, one non-interest bank, as well as five merchant banks.

A total of nine banks were randomly chosen for this research. Two banks were selected among the commercial banks with international authorization, two banks from commercial banks with national authorization, another two banks with regional authorization, two merchant banks and one non-interest bank. Access Bank, GT Bank, Ecobank, Polaris Bank, Sunrise Bank and Providus Bank made up the commercial banks with international, national and regional authorization respectively while the non-interest category was made up of Jaiz Bank. The last category was merchant bank which comprises of Rand Merchant Bank and Nova Merchant Bank. The banks were contacted and agreed to participate in the survey. Ten questionnaires were sent to each bank making a total of ninety questionnaires.

Respondents were classified into two groups according to the existence of e-commerce activity within the banks. The banks were classified as those using e-commerce and those that are not using e-commerce. According to them the websites can be used to study the effectiveness, functionalities and internet strategies of these banks. 
The objectives of discriminant analysis are to understand group differences and to predict the likelihood that an entity will belong to a particular group based on several metric independent variables. For example, discriminant analysis is used to distinguish banks using e-commerce and those that are not using e-commerce based on their perception of the complexity involved. Discriminant analysis involves deriving a variate, in the case of this research the variate is a linear combination of nine independent variables that was used to discriminate between banks that are using and those that are not using e-commerce. Discrimination is achieved by setting the variate's weight for each variable to maximize the between-group variance relative to the within group variance (Hair, Anderson, Tatham, \& Black, 2014). The linear combination for a discriminant analysis (discriminant function) in the two-group case is derived from an equation that takes the following form:

$$
Z=A+W 1 X 1+W 2 X 2+\ldots \ldots+W n X n
$$

Where:

$\mathrm{Z}=$ discriminant $\mathrm{Z}$ score of the discriminant function

$\mathrm{A}=$ intercept

$\mathrm{Wi}=$ discriminant weight for independent variable $\mathrm{i}$

$\mathrm{Xi}=$ independent variable $\mathrm{i}$ (Hair et al., 2014)

Statistical significance test of the discriminant function is a generalized measure of the distance between the banks that are using and those that are not using e-commerce group centroid (group mean). The main assumptions in deriving the discriminant functions are multivariate normality of the independent variables and unknown (but equal) dispersion and covariance structures (matrices) for the groups as defined by the dependent variable (Hair et al., 2014). 
Table 1: T-Test between Banks with E-Commerce Adoption and Banks without E-Commerce Adoption

\begin{tabular}{|c|c|c|c|c|c|}
\hline Item & Description & $\mathbf{T}$ & df & $\begin{array}{l}\text { Sig. }(2- \\
\text { tailed) }\end{array}$ & $\begin{array}{l}\text { Mean } \\
\text { Difference }\end{array}$ \\
\hline \multicolumn{6}{|c|}{ Top Management Support (MS) } \\
\hline MS1 & $\begin{array}{l}\text { Management is interested in the use of electronic } \\
\text { commerce }\end{array}$ & 6.482 & 46 & .000 & 1.741 \\
\hline MS2 & $\begin{array}{l}\text { Management is supportive of the use of } \\
\text { electronic commerce in business operations }\end{array}$ & 10.230 & 46 & .000 & 2.053 \\
\hline MS3 & $\begin{array}{l}\text { Our business has a clear vision on electronic } \\
\text { commerce }\end{array}$ & 7.833 & 46 & .000 & 1.847 \\
\hline MS4 & $\begin{array}{l}\text { Our vision of electronic commerce activities is } \\
\text { widely communicated and understood } \\
\text { throughout the organization }\end{array}$ & 11.644 & 46 & .000 & 2.497 \\
\hline \multicolumn{6}{|c|}{ IT Capability (IT) } \\
\hline IT1 & $\begin{array}{l}\text { Our organization is well computerized with LAN } \\
\text { and WAN }\end{array}$ & 5.392 & 46 & .000 & .952 \\
\hline IT2 & $\begin{array}{l}\text { We have high bandwidth connectivity to the } \\
\text { Internet }\end{array}$ & 6.395 & 46 & .000 & 1.323 \\
\hline IT3 & $\begin{array}{l}\text { We have an established enterprise-wide IT } \\
\text { infrastructure }\end{array}$ & 3.187 & 46 & .003 & .492 \\
\hline IT4 & $\begin{array}{l}\text { We have sufficient experience with network } \\
\text { based applications }\end{array}$ & 8.471 & 46 & .000 & 1.841 \\
\hline \multicolumn{6}{|c|}{ Perceived Benefits (PB): } \\
\hline PB1 & Reduce cost of business operations & 8.471 & 46 & .000 & 1.386 \\
\hline PB2 & Improve customer service & 6.292 & 46 & .000 & 1.053 \\
\hline PB3 & Improve distribution channels & 9.833 & 46 & .000 & 1.513 \\
\hline PB4 & Reap operational benefits & 9.777 & 46 & .000 & 1.265 \\
\hline PB5 & Increase ability to compete & 2.279 & 46 & .027 & .444 \\
\hline
\end{tabular}

Source: Research Finding, 2019 


\section{DISCUSSION OF FINDINGS}

\section{Top Management Support}

Management support discriminates between 'using' and 'non-using' of e-commerce. It was discovered that using e-commerce had greater support from management. All the items within this variable were significant discriminators. The mean value for using was significantly larger than the mean value for non-using. This is consistent with Orlikowski, (2013) assertion that top management support is crucial in the acquisition and diffusion of innovation.

Therefore, we conclude that top management support positively impacts e-commerce implementation. Thus hypothesis 1 is confirmed.

\section{IT Capability}

The results of the discriminant analysis indicate that IT capability is a significant factor that differentiates using of ecommerce from non-using. However, it is the least important factor among the significant factors. This somewhat supports Lacovou et al. (2015) findings that low level of IT sophistication was one of the factors that caused organizations to resist ecommerce adoption. Thus we conclude that a high level of IT resources and personnel IT knowledge will positively impact ecommerce implementation. Therefore hypothesis number 2 is confirmed.

\section{Perceived Benefit}

Perceived benefits ranked second on the structure matrix and is a significant factor that differentiates between using and non-using of ecommerce. The respondents believe that ecommerce helps reduce cost of business operations, improve customer service, improve distribution channels, and increase ability to compete. This supports Craig \& King (2013) claim that relative advantage is one of the consistent critical innovation implementation factor. Thus we conclude that a high level of perceived benefit will positively impact ecommerce. Therefore hypothesis number 3 is confirmed.

\section{CONCLUSION AND RECOMMENDATIONS}

This study is an attempt to identify the factors that determine the likelihood of the implementation of e-commerce in Nigerian banks. The objective of the study was to understand the e-commerce adoption level in banks and the factors that could drive or inhibit the use of ecommerce in the Nigerian banking industry. Results from the statistical analysis provide a picture of the implementation of e-commerce in the Nigerian banking sector. Generally, the results support all the formulated hypotheses, this is consistent with previous research in ecommerce adoption (Molla \& Licker, 2015; Grandon \& Pearson, 2014). 
A number of conclusions can be drawn from these results as follows: Firstly, banks with a strong support and commitment to e-commerce from top management are more likely to implement ecommerce. Secondly, banks that have the requisite IT capability and business resources (infrastructure and skills) for e-commerce implementation stand a better chance at implementing e-commerce. Thirdly, banks that have sound IT infrastructure in place are in a better position to adopt ecommerce.

Based on the above findings, it is therefore recommended that the banking sector should improve on the adoption and implementation of e-commerce in Nigeria. 


\section{REFERENCES}

Akbulut, A.Y. (2012). An investigation of the factors that influence electronic information sharing between state and local agencies. Proceedings of 8th Americas Conference on Information Systems, Dallas, Texas, USA, 2454-2460.

Beatty, R. C., Shim, J.P., \& Jones, M. C. (2001). Factors influencing corporate web site adoption: a time-based assessment. Information \& Management Journal, 38, 337-354.

Chung, W. and Payter, J. (2012). An evaluation of Internet Banking in New Zealand. Proceedings of the 35th Hawaii International Conference on Systems Sciences.

Chwelos, P., Banbasat, I. \& Dexter, A.S. (2011). Research report: empirical test of an EDI adoption model. Information Systems Research, 12(3), 304-21.

Cohen, W., \& Levinthal D. (2010). Absorptive capacity: A new perspective on learning and innovation. Administrative Science Quaterly, 128-152.

Craig, P.B. \& King, M. (2013). Small-firm computing: Motivators and inhibitors. MIS Quaterly, 17(1), 47-60.

Epstein, M.J. (2014). Implementing E-commerce Strategies: A guide to corporate success after the dot.com bust. Westerport: Praeger Publishers.

Grandon, E., \& Pearson, M.J. (2014). E-commerce Adoption: Perceptions of Managers/Owners of Small and Medium Sized Firms in Chile. Communications of the Association for Information Systems, 13, 81-102

Hair, J. F., Anderson, R. E., Tatham, R. L., \& Black, W.C. (2014). Multivariate Data Analysis. New Jersey: Prentice Hall

Khalfan, A.M. \& Akbar Abdullah (2016). Adoption an Implementation Obstacles of E-Banking Services: An Empirical Investigation of the Omani Banking Industry. In S Kamel (Ed.) Electronic Business in Developing Countries: Opportunities and Challenges, (p. 283302). Hershey: Idea Group

Lacovou, C., Benbasat, I., \& Dexter, A. (2015). Electronic data interchange and small organizations: Adoption and impact technology. MIS Quaterly, 465- 485.

Licker, P., \& Motts, N. (2010). Extending the benefits of e-commerce in Africa: Exploratory phase. Proceedings of the First Annual Conference of the Globa IT Management Association, Memphis, Tennessee, USA, 115-118. 
May, T. (1998). Social Research: Issues, Methods and Process. (2nd ed.). Buckingham: Open University Press.

Mbarika, V.W., Okoli, C., Byrd, T.A, \& Datta, P. (2015). The Neglected Continent of IS Research: A Research Agenda for Sub-Saharan Africa. Journal of the Association for Information Systems, 6(5), 130-170.

Molla, A., \& Licker, P.S. (2015) eCommerce adoption in developing countries: a model and instrument. Information \& Management, 42, 877-899.

Orlikowski, W.J. (2013). CASE tools as organizational change: Investigating incremental and radical changes in systems development. MIS Quaterly, 17(3), 309-340.

Rai, A., \& Patnayakuni, R. (2006). A structural model for CASE adoption behavior. Journal of Management Information Systems, 13(2), 205-234.

Rogers, E.M. (1983). Diffusion of innovations (3 ed.). New York: Free Press

Senn, J. (2010) Business-to-business e-commerce. Information Systems Management, Spring, 23-32.

Shore, B. (2008). IT Strategy: The Challenge of over-regulation, culture, and large scale collaborations. Journal of Global Information Technology Management, 1(1), 1-4.

Turban, E., King, D., Lee, J., \& Viehland, D. (2014). Electronic Commerce: A Managerial Perspective. New Jersey: Pearson/Prentice Hall.

Wenninger, J. (2009). The Emerging Role of Banks in E-Commerce. Current Issues in Economics and Finance, 6(3).

Zwass, V. (2013) Electronic Commerce and Organizational Innovation: Aspects and Opportunities. International Journal of Electronic Commerce. 